Journal of Jazz Studies vol. 9, no. 1, pp. 101-106 (Summer 2013)

Portrait of Cannonball: Cary Ginell's Walk Tall

\title{
Dustin Mallory
}

Walk Tall: The Music and Life of Julian "Cannonball" Adderley. By Cary Ginell. Milwaukee: Hal Leonard Books, 2013. 190 pp. \$18.99.

Very few jazz musicians can say that their band had a Top 20 single and a Top 20 album. Within that elite group of artists, only two men can state in the same breath that they also performed on jazz's best-selling album of all time, Kind of Blue. One is Miles Davis and the other is Julian "Cannonball" Adderley. Cannonball's success in album sales is just one measure of his achievements, albeit a tangible one. However, a casual stroll through the practice rooms of any jazz school in the country or jazz club in a city will aurally reveal the sheer volume of musicians that practice, perform, and revere the vocabulary that poured from Cannonball's saxophone.

Yet, despite the respect that Cannonball has been accorded over the years, both measureable and immeasurable, there is relatively little in the way of published biographical information. With the exception of the occasional feature in a periodical, an entry in The Encyclopedia of Jazz, a handful of scholarly works, and a few publications geared toward theory or discography, ${ }^{1}$ Mr. Adderley's biography has gone largely unwritten. Furthermore, it can be said definitively that there is nothing in the marketplace that even closely resembles a comprehensive biography.

Cary Ginell's Walk Tall is one of the first publications that sets theory, analysis, and discography on the back burner in favor of history/biography. The book is also the first in Hal Leonard's Jazz Biography Series, which, according to the publisher's press release for Walk Tall, will be a set of "concise and accessible jazz biographies." This description is important to keep in mind when evaluating Ginell's book. It is a very short work that hits the

${ }^{1}$ Chris Sheridan's Dis here: A Bio-Discography of Julian "Cannonball" Adderley, (Westport: Greenwood Publishing Group, 2000) is a useful resource. 
noteworthy signposts of Adderley's career without delving into academic jargon, critical theory, or any other type of deep analysis. In fact, Chapter 1, "Cannibal," details Cannonball's life from birth to age twenty-seven (19281955 ) in just eight pages! Rather, Ginell, known primarily for his work as a folklorist, radio broadcaster, journalist, and author of books on American Roots music, provides a very crisp and conventional form of biography. He succinctly states his perspective of Adderley's career in his introduction:

What Cannonball Adderley did was make jazz accessible to the average person's ears. Previously, jazz was an in-group genre. You had to get it from the inside out. With Adderley, you didn't have to understand complex chord progressions, modal scales, or arcane musical references. All you had to do was dig the groove (xv).

This statement reveals the lens through which Ginell views his subject's story.

Nevertheless, Walk Tall contains some new information that could be appealing to the layperson and researcher/academic alike., For example, Ginell provides some family history from census documents as well as the family's multi-generational relationship with Florida A\&M University. Although some of this information has been public before, Ginell's book is the first widely published source to include it. ${ }^{2}$ The author also provides an insert with rare photographs and copies of membership cards that Cannonball carried in his wallet, including his National Education Association and Broward County Teacher Association cards. Also included in the chapters titled "The New Bird" and "Cannonball Takes Charge" (Chapters 3 and 7), are brief reconstructions of Cannonball's touring history. Ginell even takes time to align the events chronologically with Cannonball's teaching engagements and recording sessions:

For the remainder of 1955 Cannonball taught school during the daytime; at night he assembled a band that played six nights a week at Porky's, a local Fort Lauderdale nightclub. The Porky's gig lasted from September

\footnotetext{
${ }^{2}$ Gig Brown's Know What I Mean: The Life and Music of Julian Cannonball Adderley (Rutgers University, 1999) and Ricky Alonzo's Julian "Cannonball" Adderley: Selected Highlights of His Life and Music (Florida State University, 2001) are two dissertations that predate Ginell's publication and also make for excellent further reading.
} 
27, 1955, until the end of January 1956; the only break came when Bob Shad flew Cannonball to New York to participate in Sarah Vaughn's inaugural session for EmArcy ... (18).

This historical retracing of Cannonball's life makes up the crux of Ginell's book. Other substantial details include well-known recording sessions, wedding information, and events surrounding Cannonball's final days.

Another significant contribution are some new interviews, most noteworthy those with Cannonball's widow, Olga Adderley Chandler. Some of the details she expounds upon may seem mundane to some readers, but they provide some insights into the character and personal life of the Adderleys. For example, Olga stated: "After we got married, Miles offered us an apartment in his townhouse. We lived way out in Queens and Julian did not want to live in town, and as much as he admired Miles, he did not want to be part of that scene" (95). Olga also revealed much about Cannonball's struggle with his health problems: "Julian's weight certainly had a lot to do with his diabetes. $\mathrm{He}$ never seriously tried losing weight but would go on minor diets and lose ten pounds. But then he'd get away from me and go out on the road and I'd find candy bars in his suitcase when he came home" (97). Olga also cleared the air about what had been known as Cannonball's nervous breakdown and near institutionalization in 1963:

He was under a lot of stress because of touring and had been having trouble with his teeth and embouchure. We were in Philadelphia and apparently he and Nat were opening at this club and had an argument and some people called me and said that Julian was crying and couldn't stop ... He was out of it for quite a while and I had to beg Dr. Leffall not to put him into an institution. While he was asleep I called my internist, who taught at NYU, Dr. Herbert Chasis ... Dr. Chasis obtained his records, so that's how I found out that he had had a minor stroke, (101102).

The only unfortunate thing about Ginell's interview material is that there is not more of it. While the concise nature of the publication leaves little room for additional interview material, there is no such thing as too many research interviews to inform a biography. By the author's own admission he only 
conducted interviews with five people who were close to Adderley for the book. This fact has created some critical backlash. ${ }^{3}$

Ginell does not attempt in any way to be musically analytical in Walk Tall, resulting in few musical insights. He does, however, sprinkle in a few details for musicians like the following: "The set included the ironically titled 'With Apologies to Oscar' (based on the chord changes to 'Sweet Georgia Brown')" (12). Ginell's musical descriptions do get sticky in some places though. One instance is when he proposes that Miles Davis "wanted to emphasize modal patterns, which are based on only the white keys of the piano, rather than the traditional Western scale system," (30). Most musicians would find this definition puzzling, but, fortunately, the book has very few of these musical missteps.

In the chapter called "Country Preacher," Ginell describes the arc of change that marked the period 1968-1970. These years are known for significant social stresses in the country as well as in jazz, and Cannonball was certainly affected by them. Ginell also goes to great lengths to discuss Cannonball's contributions as an educator in this chapter. He details Cannonball's two-day lecture/seminar programs that he conducted at colleges throughout the country in 1968 and 1969. Ginell outlines the curricular framework of an Adderley clinic and how each member of the band was expected to contribute:

Each was given a different topic to research and would then be asked to conduct individual seminars at the schools. Roy McCurdy, who studied percussion at the Eastman School of Music in Rochester, New York, gave lectures on African instruments and rhythm. Joe Zawinul, a graduate of the Vienna Conservatory, discussed the differences between European and African musical styles ... (136).

Ginell continues the chapter with a description of the Quintet's college performances and a recording session with the Los Angeles Philharmonic. The chapter ends with an account of Joe Zawinul's departure from the band. Regrettably, Ginell makes a false claim in his description of Zawinul's departure, stating: "The seeds of it were most likely planted during Miles

\footnotetext{
${ }^{3}$ See Lee Mergner's book review: Lee Mergner, "Walk Tall: The Music and Life of Julian 'Cannonball' Adderley," Jazz Times, August 2013, 70.
} 
Davis' Bitches Brew sessions in 1968, when Zawinul first met Shorter and began talking about their common aspirations" (140). First, the Bitches Brew (Columbia) sessions took place in 1969, not 1968. Second, Shorter and Zawinul had played together and known each other for several years. Both men were part of the Maynard Ferguson Orchestra which performed live at the Newport Jazz Festival in 1959 (which was incidentally Shorter's first issued recording) a full decade before the Bitches Brew sessions.

The most fascinating and controversial aspect of the book is probably Ginell's "canonization" of Cannonball's recordings. One of the most difficult aspects of writing a concise history of such a prolific musician is deciding which music to talk about and which will have to be excluded. As most biographers, Ginell makes sure to cover the commercially successful recordings: Milestones, Something Else, Kind of Blue, Nancy Wilson and Cannonball Adderley, Mercy, Mercy, Mercy, etc. However, Ginell also provides an overview of Cannonball's lesser-known later recordings in the chapters titled "Accent on Africa," "Country Preacher," and "As Ambient as All Hell." Ginell then extends his take on the Adderley canon by devoting three entire chapters to Cannonball's final work, Big Man, and a live fusion album recorded in 1971, The Black Messiah (Capitol, 1970). Ginell's description of the musical Big Man is not only a depiction of the work itself but also an account of Cannonball's final days. Ginell posits the work as the saxophonist's magnum opus. The Adderley brothers spent four years writing and finally recording the songs for the musical. Unfortunately, Cannonball did not live long enough to see the 1976 world premiere on-stage.

The emphasis placed on The Black Messiah can be viewed from multiple angles and will hopefully open some discourse on the importance of Cannonball's contribution to fusion. Part of what makes Ginell's emphasis on the album so titillating is that the album is somewhat hard to find these days; it has not been reissued on CD. ${ }^{4}$ In a sense Ginell is using his power as a biographer to historically overdub the album onto the Adderley canon. Cannonball was a pioneer of fusion, but jazz history has forgotten his contributions in favor of

${ }^{4}$ As of the time of this writing, The Black Messiah cannot be purchased new on Amazon.com or other similar sites. However, some of the material can be found on anthologies and collections like The Definitive Cannonball Adderley (Blue Note), and an import titled Walk Tall: The David Axelrod Years (EMI). 
Bitches Brew, Head Hunters, Heavy Weather, and the like. Ginell calls The Black Messiah "an intriguing and overlooked remnant from the early days of jazzrock fusion," and points out that Adderley's band spent much of 1971 and 1972 touring with another fusion forerunner known as the Mahavishnu Orchestra (145).

Finally, the organization of the book provides a solid framework for a concise biography. The "Foreword" by Quincy Jones and "Preface" by Dan Morgenstern are immense contributions to the work. Not only did both men know Adderley personally, but they are both revered figures in the history of jazz. Jones recalled setting up one of Cannonball's first recording sessions while Morgenstern describes, among other things, Adderley's participation in the now infamous "Point of Contact" debate. Both men carefully describe Cannonball's demeanor with a personal touch. Jones finishes with a short paragraph that almost acts as an epitaph. He lovingly ends with "As long as I live, Cannon will always be with us, and deep within our hearts" (x).

\section{ABOUT THE CONTRIBUTOR}

DUSTIN MALLORY is a recent graduate of the Jazz History and Research Master's program at Rutgers-Newark. He is a freelance writer and regular contributor to Cadence, The Independent Journal of Creative Improvised Music. $\mathrm{He}$ is also an active musician/educator near his home in Norristown, Pennsylvania, where he is currently working on a biography of drummer "Philly" Joe Jones. 